\title{
HYDROPYROLYSIS: IMPLICATIONS FOR RADIOCARBON PRETREATMENT AND CHARACTERIZATION OF BLACK CARBON
}

\author{
P L Ascough ${ }^{1}$ M I Bird ${ }^{2}$ W Meredith ${ }^{3}$ R E Wood ${ }^{4}$ C E Snape ${ }^{3}$ F Brock • T F G Higham $^{4} \bullet$ \\ D J Large ${ }^{3}$ D C Apperley ${ }^{5}$
}

\begin{abstract}
Charcoal is the result of natural and anthropogenic burning events, when biomass is exposed to elevated temperatures under conditions of restricted oxygen. This process produces a range of materials, collectively known as pyrogenic carbon, the most inert fraction of which is known as black carbon (BC). BC degrades extremely slowly and is resistant to diagenetic alteration involving the addition of exogenous carbon, making it a useful target substance for radiocarbon dating particularly of more ancient samples, where contamination issues are critical. We present results of tests using a new method for the quantification and isolation of BC, known as hydropyrolysis (hypy). Results show controlled reductive removal of non-BC organic components in charcoal samples, including lignocellulosic and humic material. The process is reproducible and rapid, making hypy a promising new approach not only for isolation of purified $\mathrm{BC}$ for ${ }^{14} \mathrm{C}$ measurement but also in quantification of different labile and resistant sample $\mathrm{C}$ fractions.
\end{abstract}

\section{INTRODUCTION}

Charcoal is the product of biomass exposed to high temperatures $\left(>300^{\circ} \mathrm{C}\right)$ in reducing conditions (pyrolysis). Due to a global distribution and high apparent environmental recalcitrance, charcoal is one of the most common materials submitted for radiocarbon age measurement (e.g. Bird 2006). As a result of global biomass burning, charcoal is an important component of terrestrial and marine sediments. Estimates of dry biomass consumed in modern burning events are on the order of 8700 teragrams $\mathrm{yr}^{-1}$ (Levine et al. 1992), while the long-term use of fire by human populations also means charcoal is prevalent in archaeological sites. The longevity of charcoal results from formation chemistry, as $\mathrm{H} / \mathrm{N} / \mathrm{O} / \mathrm{S}$ content falls, residual plant carbon (C) is converted into highly aromatic condensed ring formations (Eckmeier et al. 2007). The most recalcitrant fraction of pyrolyzed biomass is known as black carbon (BC). BC is operationally defined as highly aromatic, with high resistance to oxidative degradation (Schmidt et al. 2001; Simpson and Hatcher 2004; Preston and Schmidt 2006). The BC aromatic structure confers high stability as aromatic ring bond strengths are $\sim 812 \mathrm{~kJ}$ $\mathrm{mol}^{-1}$, versus $\sim 368 \mathrm{~kJ} \mathrm{~mol}^{-1}$ in C-C bonds (McMurry 1996; Maitland et al. 2005). Estimates for the half-life of pyrolyzed carbon in soils are 5-7 kyr (Preston and Schmidt 2006), compared to mean residence times for bulk soil organic carbon of $\sim 300$ and $\sim 2500$ yr in the surface and subsoil regions, respectively (Fontaine et al. 2007).

It has become apparent that charcoal forms a continuum of materials and is not a chemically homogeneous or inert substance. Pyrolysis temperature dictates the degree of aromaticity and range of chemical forms in freshly produced charcoal (Antal and Grønli 2003; Ascough et al. 2008a). In addition, it is clear that at least some charcoal has the potential to undergo postdepositional degradation (e.g. Cohen-Ofri et al. 2006), resulting in loss of charcoal from sediments and soils over decadal and longer timescales (Bird et al. 1999a, 2002). It has also been demonstrated that depositional environment controls rates of charcoal degradation; for example, several studies suggest that degradation rates may be increased in tropical regions due to generally hot and humid conditions (e.g. Bird et al. 2002; Higham et al. 2009a). Charcoal from environmental deposits may therefore comprise a range

\footnotetext{
${ }^{1}$ SUERC, Scottish Enterprise Technology Park, Rankine Avenue, East Kilbride G75 0QF, United Kingdom. ${ }^{2}$ School of Earth and Environmental Sciences, James Cook University, Cairns, Queensland 4870, Australia. ${ }^{3}$ Dept. of Chemical and Environmental Engineering, University of Nottingham, NG7 2RD, United Kingdom. ${ }^{4}$ Oxford Radiocarbon Accelerator Unit, University of Oxford, Oxford OX1 3QY, United Kingdom

${ }^{5}$ EPSRC Solid-State NMR Service, Dept. of Chemistry, Durham University, Durham DH1 3LE, United Kingdom.
}

(C) 2010 by the Arizona Board of Regents on behalf of the University of Arizona Proceedings of the 20th International Radiocarbon Conference, edited by A J T Jull RADIOCARBON, Vol 52, Nr 2-3, 2010, p 1336-1350 
of substances, including material derived from the original (unpyrolyzed) biomass, degraded components of altered charcoal, and exogenous material from the depositional environment.

A key requirement for charcoal ${ }^{14} \mathrm{C}$ pretreatment is the removal of all (contaminating) $\mathrm{C}$ not corresponding to the pyrolysis event, as this is the fraction most likely to have a different ${ }^{14} \mathrm{C}$ activity to that of the original biomass. Contamination sources include soil carbonates, humic acids, and microbial and lignocellulosic material. These may physically adhere to the sample structure, but may also be sorbed or bonded chemically to the sample; for example, porous charcoal structures are predisposed to sorptions of mobile organic carbon (e.g. DeLuca et al. 2006). Therefore, removal of all contamination types is necessary. Routine pretreatment involves washing sequentially with acid for sediment carbonate removal, followed by alkali to extract organic contaminants (including humic acids), and a final acid wash to remove any atmospheric $\mathrm{CO}_{2}$ absorbed in the base step (acid-baseacid [ABA] pretreatment). This technique is relatively rapid and appears to provide robust results for a large number of samples. However, retention and analysis of material removed into solution during ABA treatment may be impractical, and in some instances the alkali step results in the virtually complete dissolution of charred plant samples (Hedges et al. 1989; Rebollo et al. 2008). Also, the ABA technique does not always remove all contaminating carbon (e.g. Goh 1979; Gillespie et al. 1992; Harkness et al. 1994; Chappell et al. 1996; Higham et al. 1998).

This lack of control over the outcome of ABA pretreatment becomes critical with increasing sample ${ }^{14} \mathrm{C}$ age, when even small quantities of exogenous carbon can have a significant impact upon the measured sample ${ }^{14} \mathrm{C}$ activity. In some ancient charcoal samples, ABA pretreatment results in erroneously young ages (e.g. Higham et al. 2009b). Unfortunately, the age range for which sample contamination issues are particularly acute (beyond $\sim 30 \mathrm{ka} \mathrm{BP}$ ), also relates to a timeframe of key prehistoric chronologies, e.g. the spread of modern humans in Australia and western Eurasia. Bird et al. (1999b) described an alternative pretreatment technique, replacing the final ABA acid wash with oxidation in acidified potassium dichromate $\left(\mathrm{K}_{2} \mathrm{Cr}_{2} \mathrm{O}_{7}\right.$ in $\left.\mathrm{H}_{2} \mathrm{SO}_{4}\right)$ to isolate the most resistant, highly aromatic fraction of the sample (Wolbach and Anders 1989; Bird and Gröcke 1997). This is followed by stepped combustion (typically at $300{ }^{\circ} \mathrm{C}, 600^{\circ} \mathrm{C}$ and $900{ }^{\circ} \mathrm{C}$ ), to remove any final traces of labile C. The acid-base-oxidation-stepped combustion (ABOX-SC) method appears effective in removing contamination from older samples, resulting in charcoal ${ }^{14} \mathrm{C}$ ages that are more consistent with complementary dating evidence than the ABA method (Turney et al. 2001; Bird et al. 2003; Higham et al. 2009a,b). However, the rigorous ABOX-SC pretreatment is very harsh and results in large losses of sample material in many cases. This means that where available sample quantities are low or the charcoal is poorly preserved, insufficient material for dating may survive ABOX-SC (Brock and Higham 2008). This is due to the difficulty in reliably identifying a point during the ABOX-SC treatment when all contaminants are removed, but at which oxidation of the BC structure itself (and hence loss of the target material of interest for dating) has not yet commenced. Thus, there is a requirement of typically $>100 \mathrm{mg}$ of well-preserved charcoal for ABOX-SC pretreatment (Higham et al. 2009b).

Here, we report results of an alternative high-pressure hydrogen pyrolysis charcoal pretreatment technique, known as hydropyrolysis (hypy), which rapidly and reproducibly isolates the condensed aromatic structure of BC. Hypy uses catalytic addition of hydrogen to reductively separate labile and refractory components of samples. Previous work demonstrated the potential of hypy to separate and isolate BC within both pyrolyzed biomass and complex matrices such as soils (Ascough et al. 2008b). This identified operating conditions under which labile sample carbon was converted, but the resistant BC component was not degraded, facilitating removal of ${ }^{14} \mathrm{C}$ contamination while minimizing sample loss. Ascough et al. (2008b) noted that further research was required, including the need to 
chemically characterize the solid residue and products of hypy with methodologies commonly used in BC-containing matrices (e.g. Simpson and Hatcher 2004). Here, we present the results of hypy applied to a suite of charcoal samples from environmental deposits up to 50 ka in age. Sample hypy chemical changes are characterized, and the ${ }^{14} \mathrm{C}$ age of sample fractions isolated by hypy are compared with results following $\mathrm{ABA}$ and ABOX-SC pretreatment. Implications of the results for ${ }^{14} \mathrm{C}$ dating and characterization of charcoal samples from depositional environments are discussed.

\section{METHODOLOGY}

\section{Sample Materials}

Samples were selected to i) test the capacity of hypy to remove potential contaminants; ii) assess chemical changes during hypy; iii) compare the ${ }^{14} \mathrm{C}$ ages of different hypy fractions from selected samples; and iv) compare the ${ }^{14} \mathrm{C}$ ages of residue from ancient charcoal following hypy with ages for the same samples following ABA and ABOX-SC.

Samples of microcrystalline cellulose, a humic acid standard (Elliott soil; International Humic Substances Society [IHSS]) and melanoidin were used to test the capacity of hypy to remove potential contaminants. Cellulose and humic acids are regularly isolated during routine ${ }^{14} \mathrm{C}$ pretreatment techniques. Melanoidins are dark-colored heterogeneous polymers of high molecular weight produced from the Maillard reaction between sugars and amino acids, used as a proxy for organic materials likely to interfere with BC isolation (Hammes et al. 2007). The Elliott soil humic acid standard was extracted from soil under prairie vegetation where fire has been prevalent, and contains significant quantities of charcoal (6.6 g C kg-1 soil) (Skjemstad et al. 2002). Solid-state ${ }^{13} \mathrm{C}$ nuclear magnetic resonance spectroscopy with cross-polarization magic angle spinning $\left({ }^{13} \mathrm{C}-\mathrm{CP}-\mathrm{SSNMR}\right)$ shows the Elliott soil humic acid has a high concentration of aromatic C ( 50\%), relative to aliphatic C ( 26\%) (Thorn et al. 1989). A proportion of soil humic acids may be derived from BC via oxidation of pyrogenic carbon (e.g. charcoal) (Haumaier and Zech 1995). Therefore, the Elliott soil humic acid is likely to contain a proportion of native BC.

Chemical changes during hypy were assessed in 5 charcoal samples (MA, AZ, OH, TSB, and PF; Table 1). All of these samples were available in relatively large ( $>1 \mathrm{~g})$ quantities, permitting multiple analyses. For MA, weight loss, \%C loss, and ${ }^{14} \mathrm{C}$ measurements following hypy and ABA pretreatment are described in Ascough et al. (2008b); the results for the other samples are presented in Table 2. Charcoal samples were physically cleaned of all adhering materials, crushed to pass a 500$\mu \mathrm{m}$ mesh and placed in $0.5 \mathrm{M} \mathrm{HCl}$ made with Milli- $\mathrm{Q}^{\mathrm{TM}}$ ultrapure water to remove soil carbonates, then washed 3 times in ultrapure water before drying to constant weight at $50{ }^{\circ} \mathrm{C}$. Samples AZ and $\mathrm{PF}$ were also used to compare ${ }^{14} \mathrm{C}$ ages obtained after $\mathrm{ABA}$ and hypy pretreatment, and the age of labile material removed from the sample during hypy (termed "hypy product") in samples likely to be of Holocene age.

Charcoal samples FUM and ESQ (Table 1) were used to compare ${ }^{14} \mathrm{C}$ ages in charcoal residue obtained after i) hypy, ii) ABA, and iii) ABOX-SC pretreatment in samples likely to be $>25 \mathrm{ka}$ BP. It was not possible to perform analysis of chemical changes during hypy on these samples due to the limited available sample quantities. FUM was obtained from within the one of the deepest Upper Paleolithic (Aurignacian) levels at Grotte de Fumane, north Italy (Bartolomei et al. 1992; Broglio et al. 2006; Peresani et al. 2008) and was subjected to ABA and ABOX-SC by Higham et al. (2009b). Previous charcoal $\mathrm{ABA}{ }^{14} \mathrm{C}$ dates from this site are very inconsistent, with an indeterminate agedepth relationship and a range of $\sim 5000{ }^{14} \mathrm{C}$ yr for samples collected from within a single hearth (Higham et al. 2009b). ESQ was obtained from a layer deep within the stratigraphic profile at Cueva 
del Esquilleu, a Mousterian site in northern Spain (Baena et al. 2005). Previous ABA charcoal ages at ESQ range between $34,380 \pm 670$ and $49,700 \pm 1600{ }^{14} \mathrm{C}$ yr BP for levels stratigraphically higher than the charcoal sample used here (Baena et al. 2005; Zilhão 2006). Charcoal was washed in 1M $\mathrm{HCl}$ at $80^{\circ} \mathrm{C}$ for $20 \mathrm{~min}$, followed by washing 3 times in ultrapure water to remove carbonates before hydropyrolysis.

Table 1 Details for samples analyzed in this study.

\begin{tabular}{|c|c|c|c|}
\hline Sample & Location & Description & Reference \\
\hline $\mathrm{AZ}$ & $\begin{array}{l}\text { Faial Island, } \\
\text { Azores }\end{array}$ & $\begin{array}{l}\text { Charcoal concentration in the matrix of a } \\
\text { lahar deposit }\end{array}$ & $\begin{array}{l}\text { F Tempera, personal communi- } \\
\text { cation }\end{array}$ \\
\hline $\mathrm{PF}$ & $\begin{array}{l}\text { Pedra Furada, } \\
\text { Brazil }\end{array}$ & $\begin{array}{l}\text { Charcoal extracted from } 1.04-1.07 \mathrm{~m} \\
\text { depth of sand and clay deposits in a sand- } \\
\text { stone rockshelter }\end{array}$ & $\begin{array}{l}\text { Guidon and Delibrias 1985, } \\
\text { 1986; Delibrias et al. 1988; } \\
\text { Parenti 2001; Santos et al. } 2003\end{array}$ \\
\hline $\mathrm{OH}$ & $\begin{array}{l}\text { Oursi-hubeero, } \\
\text { Burkina Faso }\end{array}$ & $\begin{array}{l}\text { Charcoal within sand and clay deposits in } \\
\text { an archaeological structure dating to } \\
\sim \text { AD } 1050\end{array}$ & Hallier and Petit 2000, 2001 \\
\hline TSB & $\begin{array}{l}\text { Toca do Serrote da } \\
\text { Bastiana, Brazil }\end{array}$ & $\begin{array}{l}\text { Charcoal from deposits overlying burials } \\
\text { dated to } 200-150 \text { yr BP, in a limestone } \\
\text { rockshelter }\end{array}$ & $\begin{array}{l}\text { N Guidon, personal communi- } \\
\text { cation }\end{array}$ \\
\hline MA & $\begin{array}{l}\text { Maninjau caldera, } \\
\text { Sumatra }\end{array}$ & $\begin{array}{l}\text { Charcoal from in situ charring of trees } \\
\text { dated to } \sim 50 \mathrm{ka} \mathrm{BP}\end{array}$ & Alloway et al. 2004 \\
\hline ESQ & $\begin{array}{l}\text { Esquilleu, north- } \\
\text { ern Spain }\end{array}$ & $\begin{array}{l}\text { Charcoal from a Mousterian layer (Level } \\
\text { XIX), within an archaeological strati- } \\
\text { graphic profile }\end{array}$ & Baena et al. 2005 \\
\hline FUM & $\begin{array}{l}\text { Grotte de Fumane, } \\
\text { northern Italy }\end{array}$ & $\begin{array}{l}\text { Charcoal from a Proto-Aurignacian level } \\
\text { (layer A2, structure 17) from a cave de- } \\
\text { posit }\end{array}$ & $\begin{array}{l}\text { Bartolomei et al. 1992; Broglio } \\
\text { et al. 2006; Peresani et al. 2008; } \\
\text { Higham et al. 2009b }\end{array}$ \\
\hline Cellulose & - & Pure cellulose (Sigma Aldrich) & - \\
\hline Humic acid & Illinois, USA & Prairie soil, IHSS soil standard & $\begin{array}{l}\text { http://ihss.gatech.edu/ihss2; } \\
\text { Thorn et al. } 1989\end{array}$ \\
\hline Melanoidin & - & BC ring trial sample; negative BC control & Hammes et al. 2007 \\
\hline
\end{tabular}

Table 2 Results of elemental analysis (on an ash-free basis) on charcoal samples prior to and following hypy treatment, showing atomic $\mathrm{O} / \mathrm{C}$ ratios.

\begin{tabular}{lclrl|lll}
\hline & & \multicolumn{3}{c|}{ Untreated charcoal } & \multicolumn{3}{c}{ Hypy residue } \\
Sample & Ash content & \%C & $\% \mathrm{O}$ & O/C & \%C & $\% O$ & O/C \\
\hline AZ & 3.4 & 62.0 & 29.2 & 0.37 & 95.3 & 5.0 & 0.04 \\
PF & 16.5 & 69.8 & 27.4 & 0.35 & 79.3 & 5.9 & 0.07 \\
OH & 1.4 & 65.8 & 21.9 & 0.25 & 89.6 & 4.2 & 0.04 \\
TSB & 0.1 & 60.7 & 25.9 & 0.32 & 85.3 & 5.4 & 0.05 \\
MA & 0.3 & 78.0 & 9.1 & 0.09 & 86.5 & 3.1 & 0.03 \\
\hline
\end{tabular}

\section{Hydropyrolysis (hypy)}

Hypy was performed using the apparatus and procedure described in Ascough et al. (2008a) (see Figure 1). Aliquots for analysis were combined with a $0.2 \mathrm{M}$ solution of ammonium dioxydithiomolybdate $\left[\left(\mathrm{NH}_{4}\right)_{2} \mathrm{MoO}_{2} \mathrm{~S}_{2}\right]$ and placed on precleaned quartz wool within shortened borosilicate pipette tips in the hypy reactor. Samples were heated resistively at $300{ }^{\circ} \mathrm{C} \mathrm{min}-1$ from 50 to $250{ }^{\circ} \mathrm{C}$, then at $8{ }^{\circ} \mathrm{C} \mathrm{min}-1$ to the final temperature, which was held for $120 \mathrm{~s}$. Hypy was performed under a $\mathrm{H}_{2}$ pressure of $15 \mathrm{MPa}$ and sweep gas flow of $5 \mathrm{~L} \mathrm{~min}^{-1}$ (ATP). Hypy products were collected on silica in a dry-ice cold trap (Meredith et al. 2004). Hypy weight loss curves were produced for cellulose, humic acid, and melanoidin every $50{ }^{\circ} \mathrm{C}$ between final temperatures of 300 to $600{ }^{\circ} \mathrm{C}$. Hypy 
treatment of charcoal samples was at $600{ }^{\circ} \mathrm{C}$, on the basis of previous work suggesting this regime enabled effective removal of trace contaminants (Ascough et al. 2008a).

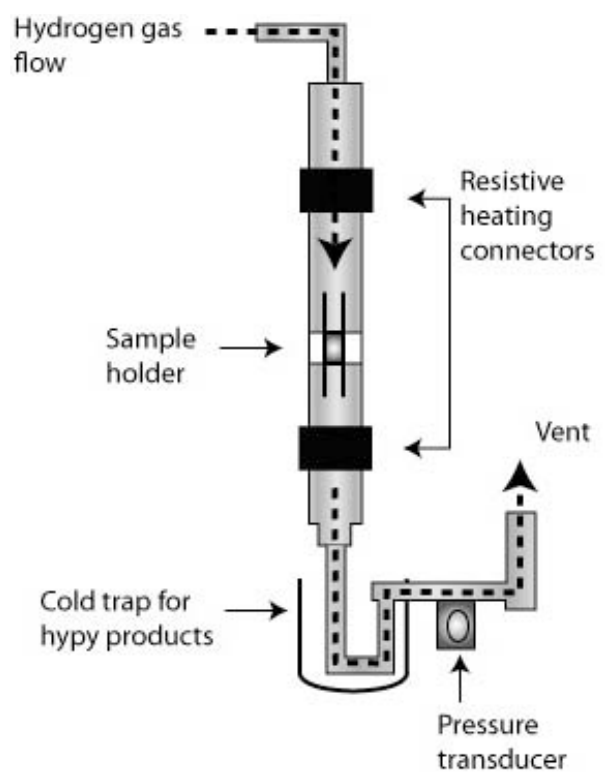

Figure 1 Schematic diagram of hydropyrolysis apparatus used for treatment of samples within this study (after Ascough et al. 2008b).

\section{Elemental Analysis}

The mineral ash content of the samples was determined by loss on ignition at $1020^{\circ} \mathrm{C}$ under air, with a multiple replicate measurement precision of $\pm 0.5 \%$. Charcoal elemental carbon (C) and oxygen (O) content was analyzed before and after hypy with a Costech elemental analyzer for \%C and a ThermoFinnigan high-temperature conversion elemental analyzer for \%O. Samples were measured in duplicate with laboratory standards and blanks; elemental abundances were calculated by comparing the gas pulse peak area to acetanilide (IAEA/Sigma Aldrich, \%C: 71.09\%, \%O: 11.84\%), with an external reproducibility of better than $0.5 \%$ for $\mathrm{C}$ and $0.7 \%$ for $\mathrm{O}$.

\section{${ }^{13} \mathrm{C}-\mathrm{CP}-S S N M R$}

Solid-state ${ }^{13} \mathrm{C}$ nuclear magnetic resonance spectroscopy with cross-polarization magic angle spinning $\left({ }^{13} \mathrm{C}\right.$-CP-SSNMR) was used to compare the $\mathrm{C}$ molecular environments of $\mathrm{AZ}$, TSB, and PF in: i) the untreated sample; ii) following oxidation in $0.1 \mathrm{M} \mathrm{K}_{2} \mathrm{Cr}_{2} \mathrm{O}_{7} / 2 \mathrm{M} \mathrm{H}_{2} \mathrm{SO}_{4}$ at $60^{\circ} \mathrm{C}$ for $4 \mathrm{hr}$ (as per the oxidation step of the ABOX-SC pretreatment); and iii) following hypy at $600{ }^{\circ} \mathrm{C}$. Spectra were also obtained of $\mathrm{AZ}$ and $\mathrm{PF}$ following digestion with $1 \mathrm{M} \mathrm{NaOH}$ at $60^{\circ} \mathrm{C}$ for $1 \mathrm{hr}$ (as per the base step of the ABA pretreatment). After oxidation or $\mathrm{NaOH}$ treatment, samples were washed 3 times to reach neutral $\mathrm{pH}$ with ultrapure water, with centrifugation between each step. The supernatant was decanted, and the residue freeze-dried prior to analysis. ${ }^{13} \mathrm{C}-\mathrm{CP}$-SSNMR spectra were recorded using a 4-mm MAS probe at a ${ }^{13} \mathrm{C}$ frequency of $100.56 \mathrm{MHz}$ on a Varian VNMRS instrument. Samples were spun at 10 or $12 \mathrm{kHz}$ with a CP contact time of 1 or $2 \mathrm{~ms}$ and a 1 -s recycle time. Spectra were referenced to neat tetramethylsilane. A rotor-synchronized spin-echo was used to suppress a broad probe background signal. 


\section{Gas Chromatography-Mass Spectrometry (GC-MS)}

Gas chromatography-mass spectrometry (GC-MS) was used to analyze the combined aliphatic and aromatic compounds retained as hypy products on silica in charcoal samples AZ, TSB, OH, and MA. These analyses were undertaken to characterize and compare the non-organized, labile carbon fraction in these samples. The products analyzed from these samples were those following the hypy program used to treat charcoal samples for ${ }^{14} \mathrm{C}$ measurement in this paper (i.e. a final hold temperature of $600{ }^{\circ} \mathrm{C}$ ). The aliphatic and aromatic fractions of the hypy products were separated by silica gel/alumina adsorption chromatography with successive elutions of $n$-hexane, $n$-hexane/DCM (3:2 $\mathrm{v} / \mathrm{v})$, and DCM/methanol (1:1 v/v). GC-MS analyses in full-scan mode were performed on a Varian CP-3800 gas chromatograph, interfaced to a 1200 mass spectrometer (EI mode, $70 \mathrm{eV}$ ). Separation was achieved on a VF-5MS fused silica capillary column ( $50 \mathrm{~m} \times 0.25 \mathrm{~mm}$ ID, $0.25 \mu \mathrm{m}$ thickness), with helium as the carrier gas, and an oven program of $50{ }^{\circ} \mathrm{C}$ (hold for $2 \mathrm{~min}$ ) to $300{ }^{\circ} \mathrm{C}$ (hold for $20.5 \mathrm{~min})$ at $4{ }^{\circ} \mathrm{C} \mathrm{min}^{-1}$.

\section{${ }^{14} \mathrm{C}$ Pretreatment and Measurement}

ABA and ABOX-SC pretreatment techniques of FUM are described in Higham et al. (2009b). One aliquot each of AZ, PF, and ESQ was pretreated by ABA, comprising sequential washes with $\mathrm{HCl}$ and $\mathrm{NaOH}$; following each wash, samples were rinsed with ultrapure water. One aliquot of ESQ was treated by ABOX-SC. ESQ and FUM were subjected to both pretreatments, while AZ and PF were only treated with the former. Specific treatment methodologies were consistent between different samples to which they were applied. To compare the ${ }^{14} \mathrm{C}$ ages of different hypy fractions from selected samples for which chemical characterizations of these fractions were available, 1 aliquot each of $\mathrm{AZ}$ and $\mathrm{PF}$ was treated with hypy at $600{ }^{\circ} \mathrm{C}$ as described above, with both the hypy residue and the hypy product collected on silica being retained for ${ }^{14} \mathrm{C}$ measurement. $\mathrm{A}{ }^{14} \mathrm{C}$ measurement was also obtained of TSB following ABA pretreatment, in order to obtain an absolute age for this sample. To compare the ${ }^{14} \mathrm{C}$ ages of ancient charcoal residue following hypy with those following ABA and ABOX-SC, 1 aliquot each of ESQ and FUM was treated with hypy at $600{ }^{\circ} \mathrm{C}$ as described above, and the hypy residue retained for ${ }^{14} \mathrm{C}$ measurement.

ABA and ABOx-SC pretreatment techniques are described in Higham et al. (2009b) and Brock et al. (2010). FUM and ESQ were treated with both protocols, while AZ and PF were treated only with the ABA protocol.

\section{RESULTS}

\section{Conversion of Non-Charcoal Material During Hypy}

The weight loss profiles for cellulose, humic acid, and melanoidin are presented in Figure 2. Catalyst weight loss was consistent at $35 \%$ for individual runs, and sample hypy weight losses were corrected to account for remaining catalyst. Cellulose weight loss was $100 \%$ by $600{ }^{\circ} \mathrm{C}$, with the majority of degradation occurring below $450{ }^{\circ} \mathrm{C}$. Replicate analyses confirmed that full conversion of cellulose was achieved via hypy. Humic acid conversion was $~ 96 \%$ by $600{ }^{\circ} \mathrm{C}$, where a proportion of residue weight ( $1 \%)$ was due to ash content. In the melanoidin sample, $100 \%$ weight loss was achieved by $525^{\circ} \mathrm{C}$.

\section{Elemental Analysis}

Ash contents were generally $<3 \%$, with a higher content in PF. All elemental abundance values were calculated on an ash-free basis. The initial \%C of the samples was $78.0 \%$ to $60.7 \%$ (Table 2). The 


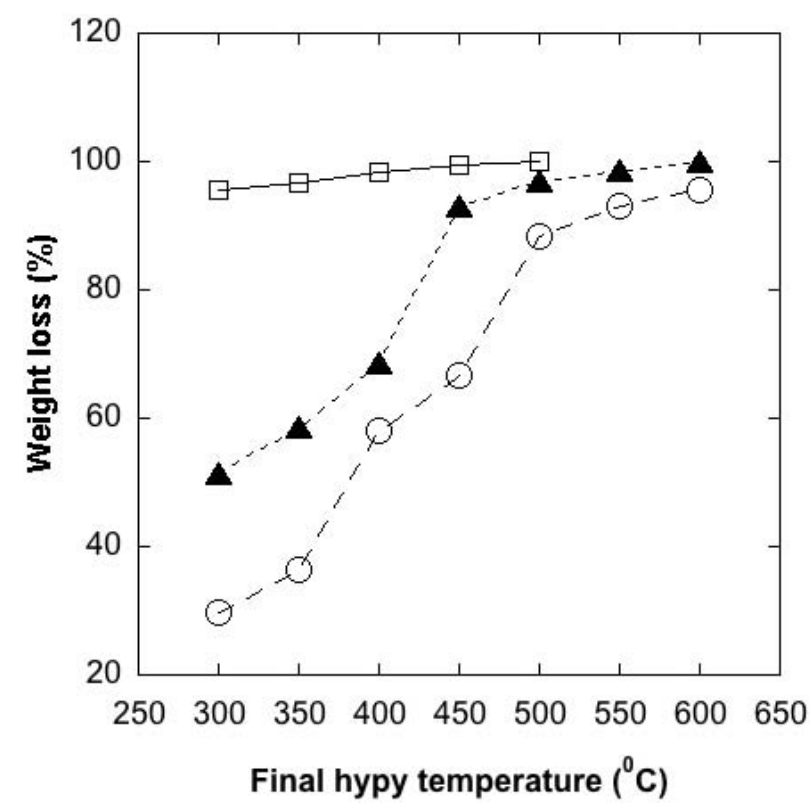

Figure 2 Weight loss profiles during hypy treatment at increasing final hold temperatures for cellulose (black triangles), humic acid (white circles) and melanoidin (white squares).

initial \%O of MA (9.1\%) was much lower than the other 4 charcoals (21.9\% to $29.2 \%)$. Atomic O/ $\mathrm{C}$ ratios of untreated charcoal samples ranged from 0.37 to 0.09 . Following hypy, sample \%C increased dramatically and the $\mathrm{O} / \mathrm{C}$ ratios of all samples fell to between 0.03 and 0.07 .

\section{${ }^{13} \mathrm{C}-\mathrm{CP}-S S N M R$}

The ${ }^{13} \mathrm{C}$-CP-SSNMR spectra of untreated PF, AZ, and TSB (Figure 3) all contain a signal in the aromatic region (110-160 ppm), centered on $\sim 130 \mathrm{ppm}$, indicative of aromatic ring structures in pyrogenic carbon (Simpson and Hatcher 2004). The weak signal at $110 \mathrm{ppm}$ in the spectrum from PF is due to interference from the Teflon ${ }^{\circledR}$ rotor cap. PF gives a single aromatic signal centered on $\sim 125$ ppm, with high- and low-frequency spinning sidebands ( ${ }^{*}$ in Figure 3), characteristic of charcoal produced at $>500{ }^{\circ} \mathrm{C}$ (Ascough et al. 2008a). NaOH and hypy treatment do not affect the spectra of this sample. After $\mathrm{K}_{2} \mathrm{Cr}_{2} \mathrm{O}_{7}$ oxidation, low-intensity signals appear at 170 and $190 \mathrm{ppm}$, indicating formation of carboxylic and ketone groups, respectively.

Along with aromatic C, AZ contains a large amount of alkyl-C at 10-50 ppm, and a peak at $55 \mathrm{ppm}$ typical of the $-\mathrm{OCH}_{3}$ group in lignin (Hatcher et al. 1989). The signal at $147 \mathrm{ppm}$ (aromatic C-O) may indicate guaiacyl lignin (Kringstad and Mörck 1983), and the signal at 170 and 200 ppm demonstrates the presence of carboxyl carbon and aldehyde or ketone groups, respectively. $\mathrm{K}_{2} \mathrm{Cr}_{2} \mathrm{O}_{7}$ oxidation removed the 55-ppm $-\mathrm{OCH}_{3}$ peak; otherwise, the spectrum was similar to the unoxidized sample, with a broad, indistinct aromatic signal suggesting carbon in a large range of aromatic structures. $\mathrm{NaOH}$ treatment resulted in a large mass loss ( $\sim 50 \%)$ and very dark supernatant, indicating a high quantity of base-soluble material in AZ. After $\mathrm{NaOH}$ treatment, a high quantity of alkyl-C and the 55-ppm - $\mathrm{OCH}_{3}$ peak remained. After hypy treatment, the only remaining signal was for (pyrogenic) condensed aromatic carbons at $\sim 130 \mathrm{ppm}$. The range of condensed aromatic structures present in this sample appears lower than that after the dichromate or alkali treatment. 


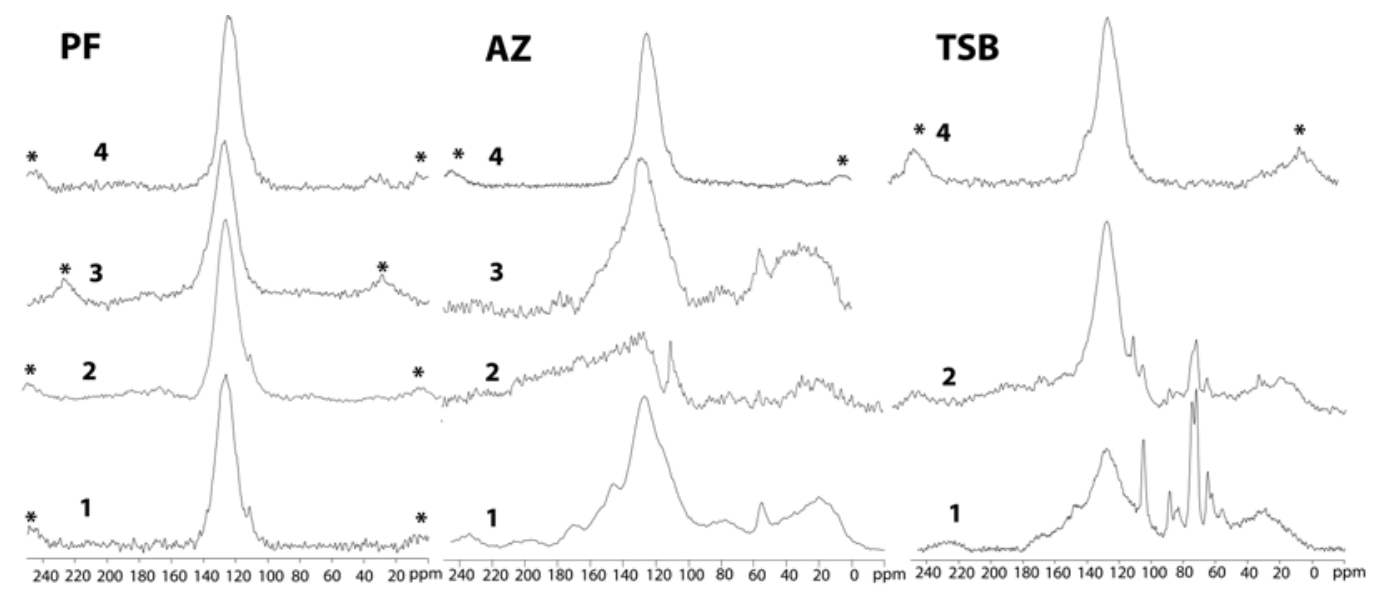

Figure $3{ }^{13} \mathrm{C}-\mathrm{CP}-S S N M R$ spectra of charcoal samples (left to right: PF, AZ TSB), 1: charcoal, 2: charcoal following $4 \mathrm{hr}$ of $\mathrm{K}_{2} \mathrm{Cr}_{2} \mathrm{O}_{7}$ oxidation, 3: charcoal following $\mathrm{NaOH}$ treatment, 4: charcoal hypy treatment. Asterisks indicate spinning sidebands in the spectra of highly aromatic samples.

Along with the aromatic signal at $130 \mathrm{ppm}$, TSB also contains peaks in the alkyl and O-alkyl C region (0-110 ppm). A broad signal at 10-40 ppm indicates the presence of aliphatic carbon $\left(-\mathrm{CH}_{3}\right.$, $>\mathrm{CH}_{2},>\mathrm{CH}-$, and $>\mathrm{C}<$ ), and resonances at 60-105 ppm are diagnostic for cellulose and hemicellulose. These include carbon in the glucopyranose ring (72-75 ppm), in the $\mathrm{CH}_{2} \mathrm{OH}$ group (62 and 65 ppm), and in glycosidic bonds ( 105, 89, and 84 ppm) (Earl and Vanderhart 1981; Atalla and Vanderhart 1999). After $\mathrm{K}_{2} \mathrm{Cr}_{2} \mathrm{O}_{7}$ oxidation, overall spectral aromaticity increased, but a significant amount of alkyl-C remained in a broad, unresolved band at 10-50 ppm. Although the relative height of the cellulosic signal decreased (indicating some degradation), peaks at 60-80 and $105 \mathrm{ppm}$ suggest intact pyranose rings and glycosidic linkages. In contrast, the signal range after hypy treatment is dramatically reduced, consisting of those from condensed aromatic structures centered on $127 \mathrm{ppm}$.

\section{Gas Chromatography-Mass Spectrometry}

GC-MS revealed that the hypy products consisted predominantly of a complex distribution of aromatic compounds (Table 3 and Figure 4). These were mainly polycyclic in nature and ranged from compounds comprising 1 aromatic ring (trimethylbenzene) to 7 peri-fused rings (coronene), with varying degrees of alkylation. The degree of alkyl substitution decreases with increasing size of polycyclic aromatic moieties. Comparison of products from the charcoal samples shows that the degree of alkyl substitution is higher in AZ and OH than it is in TSB and MA. For example, in AZ and $\mathrm{OH}$ the content of pyrene is broadly equivalent to that of methylpyrene, whereas in TSB and MA the ratio of this parent polycyclic aromatic hydrocarbon (PAH) to the alkylated PAH is much higher. It is therefore apparent from the results that GC-MS analysis of the aromatic fraction released as labile product during hypy forms a useful proxy for the non-graphitic $\mathrm{C}$ component in charcoal samples.

\section{${ }^{14} \mathrm{C}$ Pretreatment $\mathrm{ABA}$ and $\mathrm{ABOX}$ Comparison Treatments}

The ${ }^{14} \mathrm{C}$ measurement of TSB gave $129.7 \pm 0.4 \mathrm{pMC}$, indicating this sample postdated AD 1950 (Levin and Kromer 2004) (Table 4). The ${ }^{14} \mathrm{C}$ age of AZ and PF (Table 4) following hypy treatment was within error of the same sample following standard ABA treatment $(1049 \pm 24$ and $6500 \pm 40$ ${ }^{14} \mathrm{C}$ yr $\mathrm{BP}$, respectively). In $\mathrm{AZ}$, the ${ }^{14} \mathrm{C}$ age of the products extracted onto silica during hypy treat- 
Table 3 Assignments for compounds (shown in Figure 4) identified via GC-MS of hypy products from AZ, OH, TSB, and MA.

\begin{tabular}{cl}
\hline Assignment & Compound \\
\hline 1 & Trimethylbenzene \\
2 & Indane \\
3 & Naphthalene \\
4 & Methylnaphthalene \\
5 & Dimethylnaphthalene \\
6 & Trimethylnaphthalene \\
7 & Fluorene \\
8 & Methylfluorene \\
9 & Phenanthrene \\
10 & Methylphenanthrene \\
11 & Fluoranthene \\
12 & Pyrene \\
13 & Methylpyrene \\
14 & Dimethylpyrene \\
15 & Chrysene \\
16 & Methylchrysene \\
17 & Benzofluoranthene \\
18 & Benzopyrene \\
19 & Indeno(1,2,3-cd)pyrene \\
20 & Benzo(ghi)perylene \\
21 & Coronene \\
\hline
\end{tabular}
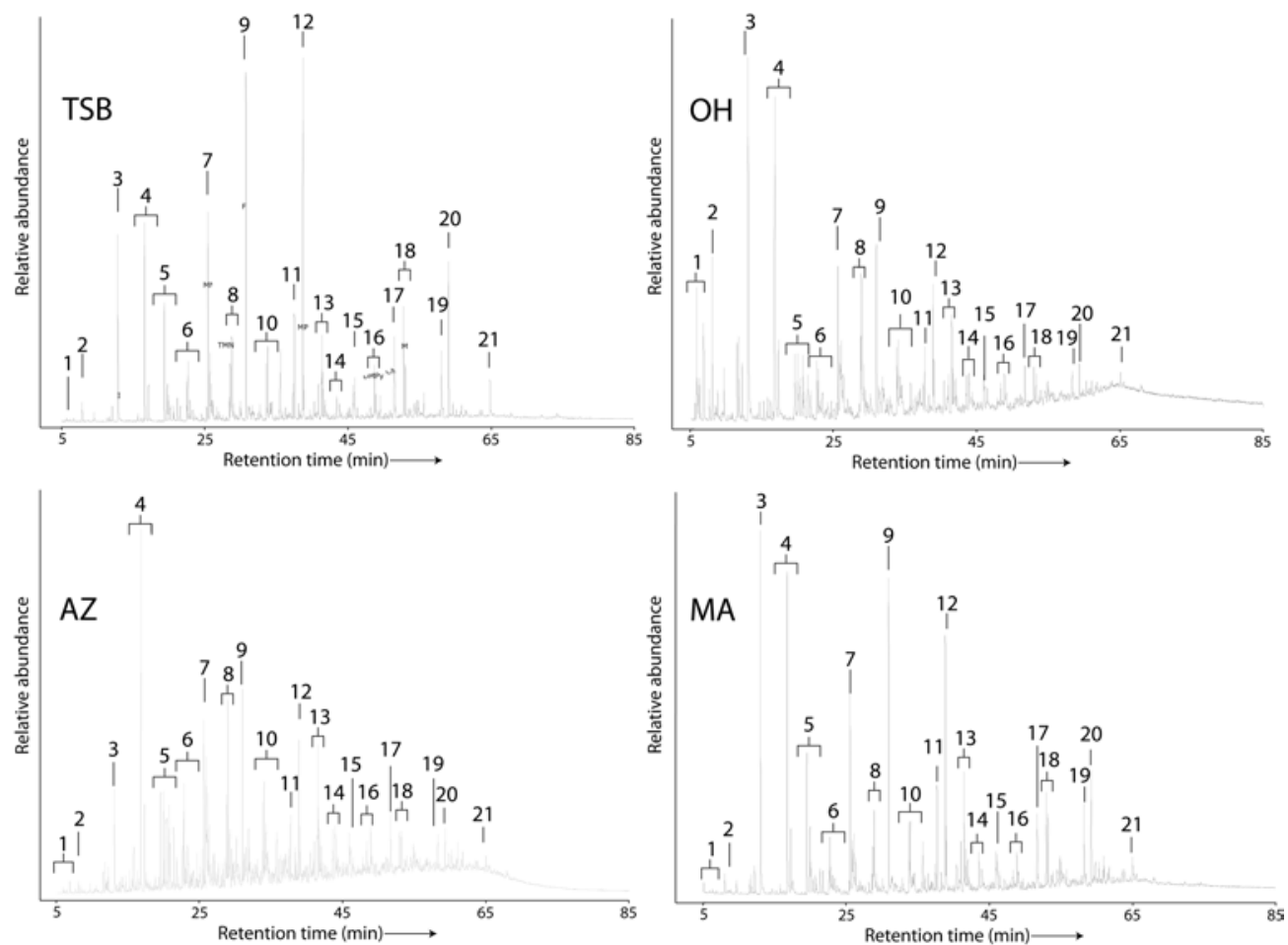

Figure 4 GC-MS chromatograms showing aromatic hydrocarbon distributions of hypy products from AZ, OH, TSB, and MA. Assignments for individual compounds numbered 1-21 are given in Table 3. 
ment $\left(1048 \pm 23{ }^{14} \mathrm{C}\right.$ yr BP) was within error of the hypy residue ${ }^{14} \mathrm{C}$ age. The ${ }^{14} \mathrm{C}$ age of hypy products from $\mathrm{PF}$ was $142 \pm 48{ }^{14} \mathrm{C}$ yr older than the hypy residue and $151 \pm 54{ }^{14} \mathrm{C}$ yr older than the ABA-treated charcoal.

Table 4 Results of ${ }^{14} \mathrm{C}$ measurement on charcoal samples following ABA and hypy treatment showing previous data obtained on pre-Holocene samples following ABA and ABOX-SC treatment ("Higham et al. 2009b).

\begin{tabular}{lllccl}
\hline Sample & Reporting $\mathrm{nr}$ & Treatment & ${ }^{14} \mathrm{C}$ age $\pm 1 \sigma$ & $\mathrm{F}^{14} \mathrm{C} \% \pm 1 \sigma$ & $\delta^{13} \mathrm{C}(\%)$ \\
\hline TSB & OxA-16026 & ABA & - & $129.72 \pm 0.41$ & -26.7 \\
PF & OxA-16028 & ABA & $6500 \pm 40$ & $44.52 \pm 0.23$ & -26.6 \\
PF & OxA-V-2268-53 & Hypy (residue) & $6509 \pm 31$ & $44.518 \pm 0.172$ & -25.7 \\
PF & OxA-V-2260-22 & Hypy (product) & $6651 \pm 37$ & $43.779 \pm 0.209$ & -24.2 \\
AZ & OxA-18945 & ABA & $1049 \pm 24$ & $87.767 \pm 0.26$ & -22.6 \\
AZ & OxA-V-2268-52 & Hypy (residue) & $1013 \pm 23$ & $88.154 \pm 0.250$ & -21.4 \\
AZ & OxA-V-2260-21 & Hypy (product) & $1048 \pm 23$ & $87.809 \pm 0.251$ & -22.3 \\
FUM & OxA-19411* & ABA & $32,530 \pm 240$ & $1.754 \pm 0.071$ & -25.6 \\
FUM & OxA-19412* & ABOX & $34,940 \pm 280$ & $1.3 \pm 0.065$ & -24.2 \\
FUM & OxA-V-2309-33 & Hypy (residue) & $30,570 \pm 210$ & $2.377 \pm 0.134$ & -21.7 \\
ESQ & OxA-19085 & ABA & $39,280 \pm 340$ & $0.763 \pm 0.06$ & -23.5 \\
ESQ & OxA-19086 & ABOX & $>54,600$ & $0.077 \pm 0.049$ & -23.0 \\
ESQ & OxA-V-2309-41 & Hypy (residue) & $45,200 \pm 1000$ & $0.517 \pm 0.131$ & -22.1 \\
\hline
\end{tabular}

ABA pretreatment of ESQ resulted in an age of 39,280 $\pm 340{ }^{14} \mathrm{C}$ yr BP (Table 4). The hypy-treated residue from this sample was significantly older, at $45,200 \pm 1000{ }^{14} \mathrm{C}$ yr BP. After ABOX-SC treatment, ESQ yielded an infinite age $\left(>54,600{ }^{14} \mathrm{C}\right.$ yr BP). The ${ }^{14} \mathrm{C}$ age of FUM after hypy treatment was $30,570 \pm 210{ }^{14} \mathrm{C}$ yr BP (Table 4). This is younger than the ABOX-SC $\left(34,940 \pm 280{ }^{14} \mathrm{C}\right.$ yr BP) and ABA (32,530 $\pm 240{ }^{14} \mathrm{C}$ yr BP) age for this sample obtained by Higham et al. (2009b).

\section{DISCUSSION}

In Holocene-age samples, the ${ }^{14} \mathrm{C}$ age of the hypy residue is equivalent to the ABA-treated charcoal. This is consistent with previous results from the hypy residue of a Holocene charcoal from a Portuguese archaeological site (Ascough et al. 2008a). Contaminating $C$ in these samples is therefore either present in insufficient quantities to significantly affect overall ${ }^{14} \mathrm{C}$ age, and/or of a chemical form that is labile in all pretreatments. In sample PF, small quantities of older contamination are removed by hypy. In this sample, the ${ }^{14} \mathrm{C}$ age of the hypy product from $\mathrm{PF}$ shows removal of older exogeneous C. However, PF is dominantly composed of condensed aromatic C, and there are few ${ }^{13} \mathrm{C}$-CP-SSNMR spectral changes during hypy, suggesting the older $\mathrm{C}$ in the hypy product comprised a minimal proportion of overall sample $\mathrm{C}$, relative to the $\mathrm{BC}$ fraction.

Contamination that has little effect on the ${ }^{14} \mathrm{C}$ age could be a general feature of relatively young charcoal samples. For example, comparing the standard ABA and more aggressive ABOX-SC pretreatments, Higham et al. (2009a) found no significant difference in ${ }^{14} \mathrm{C}$ age in samples $<25 \mathrm{ka} \mathrm{BP}$. It is also important to consider that these results could also arise if a significant proportion of the labile $\mathrm{C}$ removed during charcoal pretreatment is contemporaneous with the sample $\mathrm{BC}$ component (i.e. relates to the same pyrolysis event). This could occur if the labile $\mathrm{C}$ represents degradation products of either incompletely charred initial sample lignocellulosic material (e.g. Kaal et al. 2008), or postdepositional charcoal alteration without addition of $C$ of different ${ }^{14} \mathrm{C}$ activity. This appears to be the case in one of the samples (i.e. AZ) for which we obtained a ${ }^{14} \mathrm{C}$ age of the different hypy fractions. ${ }^{13} \mathrm{C}-\mathrm{CP}-\mathrm{SSNMR}$ spectra of AZ show that labile $\mathrm{C}$ is largely composed of humic 
material (e.g. Laird et al. 2008). The $~ 50 \%$ mass loss during $\mathrm{NaOH}$ treatment shows this comprises a large proportion of the sample. GC-MS of the hypy products of AZ are dominantly aromatic, which suggests a pyrogenic origin for the humic material removed during pretreatment rather than exogenous substances of equivalent ${ }^{14} \mathrm{C}$ age to the pyrolysis event.

These results highlight the importance of understanding the origin and variety of different chemical fractions that may exist within charcoal samples. An advantage of hypy in this regard is the ability to separate and retain different sample fractions for analysis, both in terms of ${ }^{14} \mathrm{C}$ measurement and chemical characterization. The latter includes the ability to reproducibly quantify labile versus resistant (i.e. BC) sample C (e.g. Ascough et al. 2008b).

The results demonstrate that hypy treatment results in complete removal of cellulose and melanoidin by $\sim 550^{\circ} \mathrm{C}$. Likewise, the vast majority of the Elliott soil humic acid is removed under these conditions, despite the highly aromatic nature of this sample. This is encouraging as it demonstrates that hypy removes aromatic chemical forms that do not consist of the condensed aromatic configurations of native BC. Furthermore, measured O/C atomic ratios and ${ }^{13} \mathrm{C}-\mathrm{CP}$-SSNMR spectra prove that hypy facilitates removal of oxygen-containing functional groups and all non-aromatic $\mathrm{C}$ in charcoal samples (Table 2 and Figure 3). This is achieved in samples containing cellulosic carbon (e.g. TSB) and humic material (e.g. AZ). The lack of aliphatic-derived compounds identified via GC-MS of the hypy products from TSB indicates that cellulosic material is readily degraded during hypy and removed in gaseous form. In contrast, a significant proportion of non-aromatic carbon evidently survives the $\mathrm{K}_{2} \mathrm{Cr}_{2} \mathrm{O}_{7}$ (ABOX) oxidation for at least $4 \mathrm{hr}$. This highlights the requirement for extended oxidation periods (e.g. $20 \mathrm{hr}$, cf. Higham et al. 2009a) during application of the ABOX-SC technique. Cellulosic structures are chemically susceptible to such harsh oxidation; therefore, the persistence of this material may indicate protection from the $\mathrm{K}_{2} \mathrm{Cr}_{2} \mathrm{O}_{7}$ solution. This may occur physically (e.g. in pore spaces), as non-BC biomass fractions can survive several hours of $\mathrm{K}_{2} \mathrm{Cr}_{2} \mathrm{O}_{7}$ oxidation due to hydrophobicity (Knicker et al. 2007). Alternatively, this protection may arise chemically, by complexing with more resistant fractions such as lignin (Jin et al. 2006). Such mechanisms may also be responsible for the persistence of a substantial proportion of aliphatic alkyl-C within sample AZ following $\mathrm{NaOH}$ treatment, despite the increased proportion of condensed aromatic carbon. Hypy therefore seems to effectively degrade materials commonly targeted for isolation in ${ }^{14} \mathrm{C}$ pretreatment at the tested operating conditions. Despite large differences in the chemistry of initial charcoal samples, hypy appears to isolate a highly consistent, condensed aromatic fraction in a range of samples.

The results indicate the potential advantages in further adaptation of the hypy program in order to remove possible fine exogenous $\mathrm{BC}$ contamination from charcoal samples. A small proportion of the Elliott humic acid sample is likely to consist of an original BC component introduced by repeated burning of the prairie soil; in such soils, a proportion of extractable humic acids appears to be derived from pyrogenic carbon (Haumier and Zech 1995). Depolymerization and surface oxidation of charcoal during diagenesis produces oxidized, weakly condensed aromatic structures, which appear chemically similar to highly aromatic humic substances extracted from soils (Haumier and Zech 1995; Kramer et al. 2004; Knicker et al. 2006; Knicker 2007; Kaal et al. 2008). Therefore, the $\sim 3 \%$ highly resistant component in the Elliott soil sample is likely to represent a native BC component present in the humic acid itself. Such components are likely to comprise a very small component of bulk organic carbon in soils and sediments; however, they have the potential to influence charcoal ${ }^{14} \mathrm{C}$ ages, particularly in more ancient samples. This is important as such a component is likely to be chemically highly resistant and structurally similar to the BC target material of interest in the charcoal samples, making isolation in pretreatment difficult. The thermal stability of BC materials increases in proportion to the size of polyaromatic domains and molecular weight (Venka- 
taraman and Friedlander 1994). This means that removal of forms of exogenous BC may be possible if pretreatment were targeted to result in preferential loss of more weakly aromatized chemical forms, and those consisting of a smaller number of aromatic rings.

The hypy regime selected in this work $\left(600^{\circ} \mathrm{C}\right.$ with hold time of $2 \mathrm{~min}$ ) was chosen in order to optimize $\mathrm{BC}$ recovery while removing maximum amounts of $\mathrm{C}$ contamination. This results in loss of a small quantity of sample BC (Ascough et al. 2008b); however, a more aggressive regime may be required in older samples where contamination by exogenous BC is a problem. For example, increasing the hypy hold time at final temperature would result in a more aggressive treatment with the aim of preferentially removing smaller condensed aromatic domains, as in the combustion step of the ABOX-SC treatment. This could be a desirable approach, for example, in samples containing $\mathrm{BC}$ components derived from humic substances in soils with high native charcoal contents.

In the 2 charcoal samples $>25 \mathrm{ka} \mathrm{BP}$ tested here, the results suggest that this material contains separate $\mathrm{C}$ fractions with significantly different ${ }^{14} \mathrm{C}$ activity. The fraction isolated by $\mathrm{ABOX}$-SC in both ESQ and FUM has the lowest ${ }^{14} \mathrm{C}$ activity in both instances. Previous work shows that the combustion steps at $330{ }^{\circ} \mathrm{C}$ and above removes $\mathrm{C}$ contamination not isolated via the $\mathrm{K}_{2} \mathrm{Cr}_{2} \mathrm{O}_{7}$ oxidation (Bird et al. 1999b; Turney et al. 2001). In light of the above discussion, it is possible that sample polycyclic aromatic BC compounds of differing thermal stability have significantly different ${ }^{14} \mathrm{C}$ ages, and a key factor in pretreatment of such samples is removal of this proportion of the sample $\mathrm{BC}$ component. Although a ${ }^{14} \mathrm{C}$ age is not available for the hypy products (i.e. the labile $\mathrm{C}$ fraction) from samples FUM and ESQ, in ESQ the ${ }^{14} \mathrm{C}$ activity of material isolated by hypy is significantly older than that isolated by ABA. Both results presented here (e.g. consistency of elemental composition and ${ }^{13} \mathrm{C}$-CP-SSNMR spectra of hypy residues from different charcoal samples) and previous work has established that hypy is a highly reproducible method (Ascough et al. 2008b). Therefore, the material isolated by hypy in ESQ and FUM is likely to be chemically similar. However, in FUM the ${ }^{14} \mathrm{C}$ activity of this fraction is higher than that of the fraction isolated by ABA. This highlights the fact that similar chemical components can have very different ${ }^{14} \mathrm{C}$ activities relative to overall sample ${ }^{14} \mathrm{C}$ activity. Such features also extend to the ABOX-SC method in certain instances; for example, in the Niah Cave sequence, ABOX-SC of charcoal from context $2079(\sim 21 \mathrm{ka} B P)$ resulted in a younger ${ }^{14} \mathrm{C}$ age than either the untreated or ABA-treated charcoal (Higham et al. 2009a). However, in the remainder of the sequence, $\mathrm{ABOX}$-SC returned the oldest ${ }^{14} \mathrm{C}$ ages. This highlights a key issue in ${ }^{14} \mathrm{C}$ measurement of ancient charcoal samples, where small amounts of carbon with a varying ${ }^{14} \mathrm{C}$ activity can have a large impact on measured sample age.

Hypy offers specific practical methodological advantages in pretreatment of charcoal samples for ${ }^{14} \mathrm{C}$ measurement, notably rapidity of processing and minimization of sample losses in pretreatment. The results suggest that hypy is more rapid and effective in removing non-BC sample components than even aggressive oxidation regimes. Following treatment, the sample hypy residue is suitable for direct combustion to $\mathrm{CO}_{2}$, with no further isolation steps required, representing a considerable advantage when processing samples rapidly degraded during conventional pretreatment. The results also highlight the ability to readily characterize different sample components via analysis of different hypy fractions, providing valuable information on the composition of labile versus resistant carbon in charcoal samples. For example, GC-MS analysis of hypy products suggests larger polyaromatic domains exist within samples MA and TSB, relative to AZ and $\mathrm{OH}$. This may be related either to pyrolysis conditions (i.e. temperature) or be indicative of postdepositional degradation of the charcoal/BC structure. Improved pretreatment of charcoal samples close to the ${ }^{14} \mathrm{C}$ dating limit requires a better understanding of the chemistry of different potential environmental sources of contaminating ${ }^{14} \mathrm{C}$, and the mechanisms by which different pretreatment methods remove or alter these carbon 
forms. Such understanding will enable improvements in specificity of pretreatment techniques, and hence significant improvements in accuracy of charcoal ${ }^{14} \mathrm{C}$ age measurement in key areas.

\section{CONCLUSIONS}

The results of this study support the interpretation that hypy is able to reproducibly and rapidly isolate the most resistant BC fraction from carbonaceous samples. A consistent highly aromatic component is isolated in charcoal with different starting compositions, including samples containing significant quantities of cellulosic and humic material. It is also apparent that hypy is able to effectively degrade compound classes routinely targeted for isolation in ${ }^{14} \mathrm{C}$ pretreatment. In samples of Holocene age, the ${ }^{14} \mathrm{C}$ age of solid charcoal residue isolated by hypy is equivalent to that of standard pretreatment procedures. In samples $>30 \mathrm{ka} \mathrm{BP}$, comparison of charcoal ${ }^{14} \mathrm{C}$ ages following $\mathrm{ABOX}-$ SC, ABA, and hypy treatment highlights the importance of recognizing a continuum in the chemistry of different charcoal samples, and potential sources of ${ }^{14} \mathrm{C}$ contamination that relates both to production conditions and depositional environment.

\section{ACKNOWLEDGMENTS}

Funding for this research was provided by NERC standard grant NE/F017456/1 and NERC-ORADS grant NF/2007/2/10. Funding for ABA and ABOX-SC measurements on ESQ was provided by HUM2004-04679 project of the Ministerio de Educación y Ciencia (Spain). ${ }^{13} \mathrm{C}-\mathrm{CP}-S S N M R$ measurements were performed at the EPSRC Solid-State NMR Service, Durham. The authors gratefully acknowledge the assistance of the staff of the Oxford University Accelerator Unit for ${ }^{14} \mathrm{C}$ measurements. Charcoal samples were made available for analysis with the kind assistance of Javier Baena, Julià Maroto, Brent Alloway, Alexandra Hohn, and Neide Guidon. This research represents a contribution from SAGES (The Scottish Alliance for Geosciences, Environment and Society).

\section{REFERENCES}

Alloway BV, Pribadi A, Westgate JA, Bird M, Fifield LK, Hogg A, Smith I. 2004. Correspondence between glass-FT and AMS ${ }^{14} \mathrm{C}$ ages of silicic pyroclastic density current (PDC) deposits sourced from Maninjau caldera, west-central Sumatra. Earth and Planetary Science Letters 227(1-2):121-33.

Antal MJ, Grønli MG. 2003. The art, science, and technology of charcoal production. Industrial \& Engineering Chemistry Research 42(8):1619-46.

Ascough P, Bird MI, Wormald P, Snape CE, Apperley D. 2008a. Influence of pyrolysis variables and starting material on charcoal stable isotopic and molecular characteristics. Geochimica et Cosmochimica Acta 72(24):6090-102.

Ascough PL, Bird MI, Brock F, Higham TFG, Meredith W, Snape C, Vane CH. 2008b. Hydropyrolysis as a new tool for radiocarbon pretreatment and the quantification of black carbon. Quaternary Geochronology 4(2):140-7.

Atalla RH, VanderHart DL. 1999. The role of solid state ${ }^{13} \mathrm{C}$ NMR spectroscopy in studies of the structure of native celluloses. Solid State Nuclear Magnetic Resonance 15(1):1-19.

Baena J, Carrión E, Manzano I, Velázquez R, Sanz E, Sánchez S, Ruiz B, Uzquiano P, Yravedra J. 2005. Ocupa- ciones musterienses en la comarca de Liébana (occidente de Cantabria): la cueva de El Esquilleu. In: Santonja M, Pérez-Gonzalez A, Machado M, editors. Geoarqueología y patrimonio en la Península Ibérica y el entorno Mediterráneo. Adema: Almazán. p 113-25.

Bartolomei G, Broglio A, Cassoli P, Castelletti L, Cremaschi M, Giacobini G, Malerba G, Maspero A, Peresani M, Sartorelli A, Tagliacozzo A. 1992. La GrotteAbri de Fumane. Un site Aurignacien au Sud des Alps. Preistoria Alpina 28:131-79.

Bird MI. 2006. Radiocarbon dating of charcoal. In: Elias SA, editor. The Encyclopaedia of Quaternary Science. Amsterdam: Elsevier. p 2950-7.

Bird MI, Gröcke DR. 1997. Determination of the abundance and carbon isotope composition of elemental carbon in sediments. Geochimica et Cosmochimica Acta 61(16):3413-23.

Bird MI, Moyo E, Veenendaal E, Lloyd JJ, Frost P. 1999a. Stability of elemental carbon in a savanna soil. Global Biogeochemical Cycles 13(4):923-32.

Bird MI, Ayliffe LK, Field LK, Turney CSM, Cresswell RG, Barrows TT, David B. 1999b. Radiocarbon dating of 'old' charcoal using a wet oxidation-stepped combustion procedure. Radiocarbon 41(2):127-40.

Bird MI, Turney CSM, Fifield LK, Jones R, Ayliffe LK, 
Palmer A, Cresswell RG, Robertson S. 2002. Radiocarbon analysis of the early archaeological site of Nauwalabila 1, Arnhem Land, Australia: implications for sample suitability and stratigraphic integrity. Quaternary Science Reviews 21(8-9):1061-75.

Bird MI, Fifield LK, Santos GM, Beaumont PB, Zhou Y, di Tada ML, Hausladen PA. 2003. Radiocarbon dating from 40 to $60 \mathrm{ka}$ BP at Border Cave, South Africa. Quaternary Science Reviews 22(8-9):943-7.

Brock F, Higham TFG. 2008. AMS radiocarbon dating of Paleolithic-aged charcoal from Europe and the Mediterranean Rim using ABOx-SC. Radiocarbon 51(2): 839-46.

Brock F, Higham TFG, Ditchfield P, Bronk Ramsey C. 2010. Current pretreatment methods for AMS radiocarbon dating at the Oxford Radiocarbon Accelerator Unit (ORAU). Radiocarbon 52(1):103-12.

Broglio A, De Stefani M, Tagliacozzo A, Gurioli F, Facciolo A. 2006. Aurignacian dwelling structures, hunting strategies and seasonality in the Fumane Cave (Lessini Mountains). In: Vasil'ev SA, Popov VV, Anikovich MV, Praslov ND, Sinitsyn AA, Hoffecker JF, editors. Kostenki \& the Early Upper Paleolithic of Eurasia: General Trends, Local Developments. Saint Petersburg: Nestor-Historia Publications. p 263-8.

Chappell J, Head MJ, Magee J. 1996. Beyond the radiocarbon limit in Australian archaeology and Quaternary research. Antiquity 70(269):543-52.

Cohen-Ofri I, Weiner L, Boaretto E, Mintz G, Weiner S. 2006. Modern and fossil charcoal: aspects of structure and diagenesis. Journal of Archaeological Science 33(3):428-39.

Delibrias G, Guidon N, Parenti F. 1988. The Toca do Boqueirão do Sítio da Pedra Furada: stratigraphy and chronology. In: Early Man in the Southern Hemisphere. Supplement to Archaeometry: Australasian Studies. University of Adelaide, Department of Physics and Mathematics. p S3-S11.

DeLuca TH, MacKenzie MD, Gundale MJ, Holben WE. 2006.Wildfire-produced charcoal directly influences nitrogen cycling in forest ecosystems. Soil Science Society of America Journal 70:448-53.

Earl WL, VanderHart DL. 1981. Observations by highresolution carbon-13 nuclear magnetic resonance of cellulose I related to morphology and crystal structure. Macromolecules 14:570-4.

Eckmeier E, Gerlach R, Skjemstad JO, Ehrmann O, Schmidt MWI. 2007. Only small changes in soil organic carbon and charcoal found one year after experimental slash-and-burn in a temperate deciduous forest. Biogeosciences Discussions 4:595-614.

Fontaine S, Barot S, Barré P, Bdioui1 N, Mary B, Rumpel C. 2007. Stability of organic carbon in deep soil layers controlled by fresh carbon supply. Nature 450(7167): 277-80.

Gillespie R, Hammond AP, Goh KM, Tonkin PJ, Lowe DC, Sparks RJ, Wallace G. 1992. AMS radiocarbon dating of a Late Quaternary tephra site at Graham's
Terrace, New Zealand. Radiocarbon 34(1):21-8.

Goh KM. 1979. Contaminants in charcoals used for radiocarbon dating. New Zealand Journal of Science 22: 39-47.

Guidon N, Delibrias G. 1985. Inventaire des sites SudAmericains Anterieurs a 12000 ans. L'Anthropologie 89(3):385-408.

Guidon N, Delibrias G. 1986. Carbon-14 dates point to man in the Americans 32,000 years ago. Nature 321(6072):769-71.

Hallier M, Petit LP. 2000. Tertres d'occupation et d'autre formes d'habitation à l'âge de Fer: rapport préliminaire de la campagne archéologique en été 2000 au nord du Burkina Faso. Nyame Akuma 54:2-5.

Hallier M, Petit LP. 2001 Fouille d'une maison de l'Age du Fer dans le nord du Burkina Faso. Nyame Akuma 56:2-3.

Hammes K, Schmidt MWI, Smernik RJ, Currie LA, Ball WP, Nguyen TH, Louchouarn P, Houel S, Gustafsson Ö, Elmquist M, Cornelissen G, Skjemstad JO, Masiello CA, Song J, Peng P, Mitra S, Dunn JC, Hatcher PG, Hockaday WC, Smith DM, Hartkopf-Fröder CM, Böhmer AM, Lüer B, Huebert BJ, Amelung GW, Brodowski S, Huang L, Zhang W, Gschwend PM, FloresCervantes X, Largeau C, Rouzaud J-N, Rumpel C, Guggenberger G, Kaiser K, Rodionov A, GonzalezVila FJ, Gonzalez-Pere JA, De La Rosa JM, Manning DAC, López-Capél E, Ding L. 2007. Comparison of quantification methods to measure fire-derived (black/elemental) carbon in soils and sediments using reference materials from soil, water, sediment and the atmosphere. Global Biogeochemical Cycles 21: GB3016, doi:10.1029/2006GB002914.

Harkness DD, Roobol MJ, Smith AL, Stipp JJ, Baker PE. 1994. Radiocarbon redating of contaminated samples from a tropical volcano: the Mansion "Series” of St. Kitts, West Indies. Bulletin of Volcanology 56:326-34.

Hatcher PG, Lerch I, Harry E, Bates AL, Verheyen TV. 1989. Solid-state ${ }^{13} \mathrm{C}$ nuclear magnetic resonance studies of coalified gymnosperm xylem tissue from Australian brown coals. Organic Geochemistry 14(2): 145-55.

Haumaier L, Zech W. 1995. Black carbon-possible source of highly aromatic components of soil humic acids. Organic Geochemistry 23(3):191-6.

Hedges REM, Law IA, Bronk CR, Housley RA. 1989. The Oxford Accelerator Mass Spectrometry Facility: technical developments in routine dating. Archaeometry 31(2):99-113.

Higham TFG, McGovern-Wilson RJ, Hogg AG. 1998. Chemical pretreatment and radiocarbon dating of samples from the prehistoric site of Killermont \#2, Mackenzie Basin, New Zealand. New Zealand Journal of Archaeology 18:75-90.

Higham TFG, Barton H, Turney CSM, Barker G, Bronk Ramsey C, Brock F. 2009a. Radiocarbon dating of charcoal from tropical sequences: results from the 
Niah Great Cave, Sarawak, and their broader implications. Journal of Quaternary Science 24(2):189-97.

Higham T, Brock F, Peresani M, Broglio A, Wood R, Douka K. 2009b. Problems with radiocarbon dating the Middle to Upper Palaeolithic transition in Italy. Quaternary Science Reviews 28(13-14):1257-67.

Jin Z, Katsumata KS, Lam TBT, Iiyama K. 2006. Covalent linkages between cellulose and lignin in cell walls of coniferous and nonconiferous woods. Biopolymers 83(2):103-10

Kaal J, Brodowski S, Baldock JA, Nierop KGJ, Cortizas AM. 2008. Characterisation of aged black carbon using pyrolysis-GC/MS, thermally assisted hydrolysis and methylation (THM), direct and cross-polarisation ${ }^{13} \mathrm{C}$ nuclear magnetic resonance (DP/CP NMR) and the benzenepolycarboxylic acid (BPCA) method. Organic Geochemistry 39(10):1415-26.

Knicker H. 2007. How does fire affect the nature and stability of soil organic nitrogen and carbon? A review. Biogeochemistry 85(1):91-118.

Knicker H, Almendros G, González-Vila FJ, GonzálezPérez JA, Polvillo O. 2006. Characteristic alterations of quantity and quality of soil organic matter caused by forest fires in continental Mediterranean ecosystems: a solid-state ${ }^{13} \mathrm{C}$ NMR study. European Journal of Soil Science 57:558-69.

Knicker H, Müller P, Hilscher A. 2007. How useful is chemical oxidation with dichromate for the determination of "Black Carbon" in fire-affected soils? Geoderma 142:178-96.

Kramer RW, Kujawinski EB, Hatcher PG. 2004. Identification of black carbon derived structures in a volcanic ash soil humic acid by fourier transform ion cyclotron resonance mass spectrometry. Environmental Science and Technology 38:3387-95.

Kringstad KP, Mörck R. $1983 .{ }^{13} \mathrm{C}-\mathrm{NMR}$ spectra of kraft lignins. Holzforschung 37:237-44.

Laird DA, Chappell MA, Martens DA, Wershaw RL, Thompson M. 2008. Distinguishing black carbon from biogenic humic substances in soil clay fractions. Geoderma 143:115-22.

Levin I, Kromer B. 2004. The tropospheric ${ }^{14} \mathrm{CO}_{2}$ level in mid-latitudes of the Northern Hemisphere (19592003). Radiocarbon 46(3):1261-72.

Levine JS, Cofer III WR, Cahoon Jr DR, Winsted EL, Stocks BJ. 1992. Biomass burning and global change. AIP Conference Proceedings 277:131-9.

Maitland J. 2005. Organic Chemistry. New York: W.W. Norton.

McMurry J. 1996. Organic Chemistry. 4th edition. Pacific Grove: Brooks/Cole Publishing.

Meredith W, Russell CA, Cooper M, Snape CE, Love GD, Fabbri D, Vane CH. 2004. Trapping hydropyrolysates on silica and their subsequent thermal desorption to facilitate rapid fingerprinting by GC-MS. Organic Geochemistry 35(1):73-89.

Parenti F. 2001. Le gisement quaternaire de la Toca do Boqueirão da Pedra Furada (Piaui, Brésil): stratigra- phie, chronologie, évolution culturelle. Paris: Editions Recherches sur Les Civilisations.

Peresani M, Cremaschi M, Ferraro F, Falguéres C, Bahain J-J, Gruppioni G, Sibilia E, Quarta G, Calcagnile L, Dolo J-M. 2008. Age of the final Middle Palaeolithic and Uluzzian levels at Fumane Cave, Northern Italy, using ${ }^{14} \mathrm{C}, \mathrm{ESR},{ }^{234} \mathrm{U} /{ }^{230} \mathrm{Th}$ and thermoluminescence methods. Journal of Archaeological Science 35(11):2986-96.

Preston CM, Schmidt MWI. 2006. Black (pyrogenic) carbon: a synthesis of current knowledge and uncertainties with special consideration of boreal regions. Biogeoscience 3:397-420.

Rebollo NR, Cohen-Ofri I, Popovitz-Biro R, Bar-Yosef O, Meignen L, Goldberg P, Weiner S, Boaretto E. 2008. Structural characterization of charcoal exposed to high and low $\mathrm{pH}$ : implications for ${ }^{14} \mathrm{C}$ sample preparation and charcoal preservation. Radiocarbon 50(2): 289-307.

Santos GM, Bird MI, Parenti F, Fifield LK, Guidon N, Hausladen PA. 2003. A revised chronology of the lowest occupation layer of Pedra Furada Rock Shelter, Piaui, Brazil: the Pleistocene peopling of the Americas. Quaternary Science Reviews 22(21-22):2303-10.

Schmidt MWI, Skjemstad JO, Czimczik CI, Glaser B, Prentice KM, Gelinas Y, Kuhlbusch TAJ. 2001. Comparative analysis of black carbon in soils. Global Biogeochemical Cycles 15(1):163-7.

Simpson MJ, Hatcher PG. 2004. Overestimates of black carbon in soils and sediments. Naturwissenschaften 91:436-40.

Skjemstad JO, Reicosky DC, Wilts AR, McGowan JA. 2002. Charcoal carbon in U.S. agricultural soils. Soil Science Society of America Journal 66:1249-55.

Thorn KA, Folan DW, MacCarthy P. 1989. Characterization of the International Humic Substances Society Standard and reference fulvic and humic acids by solution state carbon-13 $\left({ }^{13} \mathrm{C}\right)$ and hydrogen- $1\left({ }^{1} \mathrm{H}\right)$ nuclear magnetic resonance spectrometry. Denver: US Geological Survey, Water-Resources Investigations Report 89-4196.

Turney CSM, Bird MI, Fifield LK, Roberts RG, Smith MA, Dortch CE, Grün R, Lawson E, Ayliffe LK, Miller GH, Dortch J, Cresswell RG. 2001. Early human occupation at Devil's Lair, southwestern Australia 50,000 years ago. Quaternary Research 55(1):3-13.

Venkataraman C, Friedlander SK. 1994. Size distributions of polycyclic aromatic hydrocarbons and elemental carbon. 2. Ambient measurements and effects of atmospheric processes. Environmental Science and Technology 28(4):563-72.

Wolbach WS, Anders E. 1989. Elemental carbon in sediments: determination and spectroscopic analysis in the presence of kerogen. Geochimica et Cosmochimica Acta 53(7):1637-47.

Zilhão J. 2006. Chronostratigraphy of the Middle-to-Upper Paleolithic transition in the Iberian Peninsula. Pyrenae 37(1):7-84. 